\title{
Optimization of Groundnut (Arachis hopogaea L.) Production Technologies under Various Resource Constraints in Konkan Region
}

\author{
V.V. Sagvekar ${ }^{1}$, B.D. Waghmode ${ }^{2}$, A.S. Kamble ${ }^{2 *}$ and U.V. Mahadkar ${ }^{3}$ \\ ${ }^{1}$ ATS, Lanja, Maharashtra 416 712, India \\ ${ }^{2}$ ARS, Shirgaon, Maharashtra 415 609, India \\ ${ }^{3}$ Dr. B.S. Konkan Krishi Vidyapeeth, Agricultural Research Station, Shirgaon, \\ Tal. Dist. Ratnagiri 415629 (MS), India \\ *Corresponding author
}

\begin{abstract}
A B S T R A C T
Groundnut production depends on the genetic potential of the cultivar and the cultural practices to which the crop is subjected. There are several constraints in groundnut

Keywords

Fertilizer,

Groundnut,

Resource

constraints,

Yield,

Weeding.

Article Info

Accepted:

19 June 2017

Available Online:

10 July 2017 production viz. fertilizer, plant protection and weed management often pose serious problems. Therefore, present study was carried out to focus on such limiting factors individually or in combination which may cause more yield reduction under resource constraint. The study was formulated on lateritic soils of konkan at Agricultural Research Station, Shirgaon, Tal. Dist. Ratnagiri (MS) during Kharif 2011-2013 (three years) in Randomized Block Design with three replications which imposed of 8 different treatments. The results revealed that, application of full package as per recommendation recorded significantly highest pod yield $(3.82 \mathrm{~kg} / \mathrm{ha})$ with $1: 2.72 \mathrm{~B}: \mathrm{C}$ ratio over the full package of practices excluding fertilizer, plant protection, weed management practices in alone and also in combinations of these limiting factors. The reduction in pod yield due to exclusion of plant protection, weed and fertilizer management from full package of practices as per recommendation was to the tune of $20.81 \%, 31.46 \%$ and $39.34 \%$, respectively. However, the improvement in pod yield was followed by application of full package of practices excluding plant protection $3.03 \mathrm{t} / \mathrm{ha}$ and $1: 2.23 \mathrm{~B}: \mathrm{C}$ ratio, weed management $2.62 \mathrm{t} / \mathrm{ha}$ and 1:2.08 $\mathrm{B}: \mathrm{C}$ ratio and fertilizer management $2.32 \mathrm{t} / \mathrm{ha}$ and $1: 2.15 \mathrm{~B}: \mathrm{C}$ ratio.
\end{abstract}

\section{Introduction}

Groundnut or peanut (Arachis hypogaea L.) is also known as a 'King' of oilseed (Priya et al., 2013). Groundnut (Arachis hypogaea L.) is the $6^{\text {th }}$ most important oil seed crop in the world. It contains $48-50 \%$ oil, $26-28 \%$ protein and 11-27 \% carbohydrate, minerals and vitamin (Mukhtar, 2009). It is cultivated in $5.31 \mathrm{mha}$ area with the production of $6.96 \mathrm{mt}$ and average productivity of $1.31 \mathrm{t} / \mathrm{ha}$. The area under groundnut crop in Konkan was about 10,000 ha with $2,150 \mathrm{~kg} /$ ha productivity during rabi 2011-12 (Anonymous, 2013). Success of any crop production largely depends on use of quality seeds and agronomic management practices. The maximization of any crop yield is affected due to the use of different crop management practices such as application of recommended dose of fertilizers, plant protection measures and weed control. Farmers are not well aware about crop management practices and neglecting the application of fertilizers, use of 
plant protection measure and weed control due to paucity of funds and lack of knowledge (Patil et al., 2003). Not much attention was given on such aspect which should be given priority under the limited resources to minimize the yield reduction. Hence, present investigation was undertaken.

\section{Materials and Methods}

The field investigations were conducted with Groundnut cultivar Trombay Konkan Groundnut-Bold' (TG 19A) at Agricultural Research Station, Dr. B.S. Konkan Krishi Vidyapeeth, Shirgaon, Dist. Ratnagiri (MS) during the three consecutive kharif seasons from 2012 to 2014. There were eight treatments comprised of full package as per recommendation i.e. $\mathrm{T}_{1}, \mathrm{~T}_{2}\left(\mathrm{~T}_{1}-\right.$ Fertilizer $)$, $\mathrm{T}_{3}$ ( $\mathrm{T}_{1}-$ Plant Protection), $\mathrm{T}_{4}\left(\mathrm{~T}_{1}-\right.$ Weeding $)$, $\mathrm{T}_{5}\left(\mathrm{~T}_{1}-\right.$ Fertilizer + Plant Protection $), \mathrm{T}_{6}\left(\mathrm{~T}_{1}-\right.$ Fertilizer + Weeding $), \quad \mathrm{T}_{7}\left(\mathrm{~T}_{1}-\right.$ Plant Protection + Weeding $)$ and $\mathrm{T}_{8}\left(\mathrm{~T}_{1}-\right.$ Fertilizer + Plant Protection + Weeding) were assessed in randomized block design replicated thrice. Experimental site was high in organic matter $(1.41 \%)$, moderately acidic in reaction $(\mathrm{pH}$ 6.2) with electrical conductivity of 0.045 $\mathrm{dS} / \mathrm{m}$, medium in available nitrogen (203.50 $\mathrm{kg} \mathrm{ha}{ }^{-1}$ ) and high in available phosphorus $\left(16.15 \mathrm{~kg} \mathrm{ha}^{-1}\right)$ and available potassium (269.40 kg ha $\left.{ }^{-1}\right)$. Groundnut was sown at 30 $\mathrm{cm} \times 15 \mathrm{~cm}$ spacing with seed rate of 125 $\mathrm{kg} / \mathrm{ha}$. The recommended dose of fertilizer (25:50:00 NPK kg/ha) was applied through urea for nitrogen and phosphorus through single super phosphate. The $100 \%$ nitrogen and phosphorus was applied as basal dose. Weed control by use of pre emergence application of Pendimethalin @ $1 \mathrm{~kg} \mathrm{ha}^{-1}$ combined with one hand weeding at 30-35 days after sowing were carried out in treatments $\mathrm{T}_{4}\left(\mathrm{~T}_{1}-\right.$ Weeding $), \mathrm{T}_{6}\left(\mathrm{~T}_{1}\right.$ Fertilizer + Weeding $), \quad \mathrm{T}_{7}\left(\mathrm{~T}_{1}-\right.$ Plant Protection + Weeding $)$ and $\mathrm{T}_{8}\left(\mathrm{~T}_{1}-\right.$ Fertilizer
+ Plant Protection + Weeding). However, in plant protection measures 3 spray of contact/ systematic insecticide combined with systematic fungicides and 2 spray of for treatments $\mathrm{T}_{3}\left(\mathrm{~T}_{1}-\right.$ Plant Protection), $\mathrm{T}_{5}\left(\mathrm{~T}_{1}-\right.$ Fertilizer + Plant Protection $), \mathrm{T}_{7}\left(\mathrm{~T}_{1}-\right.$ Plant Protection + Weeding) and $\mathrm{T}_{8}\left(\mathrm{~T}_{1}-\right.$ Fertilizer + Plant Protection + Weeding) were followed to keep pest and disease population under control. Similarly, all these treatments were imposed as per the schedule and methodologies given above to specific plots.

\section{Results and Discussion}

\section{Ancillary attributes}

Pooled data presented in table 1 revealed that, number of branches/plant, number of pods/plant, shelling per cent and 100 kernel weight were significantly influenced under different resource constraint treatments. The application of full package noticed significantly higher ancillary traits over rest of treatments. However, height of plant did not reach to level of significance under application of various resource constraints treatments.

\section{Yield}

The data presented in table 2 revealed that the dry pod yield (kg/ha) was significantly highest $(3.82 \mathrm{t} / \mathrm{ha})$ in the treatment receiving full package as per recommendation i.e. $100 \%$ $\mathrm{RDF}+$ weeding + plant protection over all the treatments except treatment full package as per recommendation excluding plant protection i.e. $\mathrm{T}_{1}-\mathrm{PP}(3.03 \mathrm{~kg} / \mathrm{ha})$ which was at par with each other. Full package as per recommendation treatment significantly influenced the pod yield in all the three years of experimentation and the same was reflected in the pooled analysis. 
Table.1 Ancillary attributes of groundnut as influenced by different treatments (Pooled data of 3 years)

\begin{tabular}{|c|c|c|c|c|c|}
\hline Treatments & $\begin{array}{c}\text { Plant height }(\mathrm{cm}) \\
\text { at harvest }\end{array}$ & $\begin{array}{c}\text { No. of } \\
\text { branches/plant }\end{array}$ & $\begin{array}{l}\text { Total No. of } \\
\text { pods/plant }\end{array}$ & Shelling (\%) & 100 Kernel weight $(\mathrm{g})$ \\
\hline $\mathrm{T}_{1}$ - Full package as per recommendations & 42.7 & 3.8 & 26.4 & 71.1 & 56.7 \\
\hline $\mathrm{T}_{2}$ - Fertilizer $(\mathrm{F})$ & 44.0 & 3.4 & 17.3 & 63.6 & 54.6 \\
\hline $\mathrm{T}_{3^{-}}$Plant Protection (PP) & 42.8 & 3.5 & 23.0 & 71.7 & 54.8 \\
\hline $\mathrm{T}_{4^{-}}$Weeding $(\mathrm{W})$ & 43.9 & 3.6 & 20.3 & 68.4 & 57.3 \\
\hline $\mathrm{T}_{5^{-}}(\mathrm{F}+\mathrm{PP})$ & 42.8 & 3.0 & 13.4 & 69.5 & 54.5 \\
\hline $\mathrm{T}_{6^{-}}(\mathrm{F}+\mathrm{W})$ & 44.7 & 2.9 & 11.2 & 67.5 & 56.2 \\
\hline $\mathrm{T}_{7^{-}}(\mathrm{PP}+\mathrm{W})$ & 44.9 & 3.5 & 18.2 & 68.3 & 58.5 \\
\hline $\mathrm{T}_{8}-(\mathrm{F}+\mathrm{PP}+\mathrm{W})$ & 43.0 & 2.9 & 9.5 & 68.8 & 52.2 \\
\hline Mean & 43.6 & 3.3 & 17.4 & 68.6 & 55.6 \\
\hline $\mathrm{SE} \pm$ & 3.5 & 0.4 & 2.4 & 1.8 & 1.5 \\
\hline $\mathrm{CD}$ at $5 \%$ & NS & 1.0 & 6.7 & 5.0 & 4.1 \\
\hline $\mathrm{CV} \%$ & 8.1 & 11.1 & 13.5 & 2.6 & 2.6 \\
\hline
\end{tabular}

Table.2 Dry pod yield of groundnut as influenced by different treatments

\begin{tabular}{|c|c|c|c|c|c|}
\hline \multirow[b]{2}{*}{ Treatments } & \multicolumn{5}{|c|}{ Dry pod yield (t/ha) } \\
\hline & Kharif 2011 & Kharif 2012 & Kharif 2013 & Pooled mean & $\begin{array}{c}\text { Per cent Reduction in the } \\
\text { yield over } T_{1}\end{array}$ \\
\hline $\mathrm{T}_{1}$ - Full package as per recommendations & 4.29 & 3.80 & 3.38 & 3.82 & -- \\
\hline $\mathrm{T}_{2^{-}}$Fertilizer $(\mathrm{F})$ & 3.02 & 1.91 & 2.03 & 2.32 & 39.34 \\
\hline $\mathrm{T}_{3}$ - Plant Protection (PP) & 3.92 & 2.73 & 2.43 & 3.03 & 20.81 \\
\hline $\mathrm{T}_{4}-$ Weeding $(\mathrm{W})$ & 3.40 & 2.26 & 2.21 & 2.62 & 31.46 \\
\hline $\mathrm{T}_{5^{-}}(\mathrm{F}+\mathrm{PP})$ & 2.44 & 1.79 & 1.40 & 1.88 & 50.88 \\
\hline $\mathrm{T}_{7^{-}}(\mathrm{PP}+\mathrm{W})$ & 3.18 & 1.87 & 1.60 & 2.22 & 42.00 \\
\hline $\mathrm{T}_{8}-(\mathrm{F}+\mathrm{PP}+\mathrm{W})$ & 1.71 & 1.26 & 0.98 & 1.32 & 65.51 \\
\hline $\mathrm{SE} \pm$ & 0.17 & 0.16 & 0.11 & 0.29 & -- \\
\hline $\mathrm{CD}$ at $5 \%$ & 0.52 & 0.47 & 0.33 & 0.82 & -- \\
\hline $\mathrm{CV} \%$ & 9.9 & 12.5 & 10 & 12.3 & -- \\
\hline
\end{tabular}


Table.3 Dry pod, kernel, haulm yield and input based economics of groundnut as influenced by different treatments (Pooled data of 3 years)

\begin{tabular}{|c|c|c|c|c|c|c|c|}
\hline Treatments & $\begin{array}{l}\text { Dry pod yield } \\
\text { (t/ha) }\end{array}$ & $\begin{array}{c}\text { Kernel } \\
\text { yield } \\
\text { (t/ha) } \\
\end{array}$ & $\begin{array}{c}\text { Dry Haulm yield } \\
(\mathrm{t} / \mathrm{ha})\end{array}$ & $\begin{array}{l}\text { Gross Returns } \\
\left(\mathbf{x 1 0}^{3} ₹ \text { ha }^{-1}\right)\end{array}$ & $\begin{array}{c}\text { Cost of Cultivation } \\
\left(\mathrm{x}^{3} 0^{3} ₹ \mathrm{ha}^{-1}\right)\end{array}$ & $\begin{array}{l}\text { Net Returns } \\
\left(\mathbf{x 1 0}^{3} ₹ \mathbf{h a}^{-1}\right)\end{array}$ & $\begin{array}{l}\text { B:C } \\
\text { Ratio }\end{array}$ \\
\hline $\mathrm{T}_{1}$ - Full package as per recommendations & 3.82 & 2.72 & 4.39 & 125.8 & 46.2 & 79.1 & 2.72 \\
\hline $\mathrm{T}_{2}$ - Fertilizer $(\mathrm{F})$ & 2.32 & 1.55 & 3.13 & 77.0 & 35.8 & 40.8 & 2.15 \\
\hline $\mathrm{T}_{3}$ - Plant Protection (PP) & 3.03 & 2.09 & 3.89 & 103.9 & 44.6 & 54.6 & 2.23 \\
\hline $\mathrm{T}_{4}-$ Weeding $(\mathrm{W})$ & 2.62 & 1.80 & 3.75 & 88.8 & 41.8 & 44.7 & 2.08 \\
\hline $\mathrm{T}_{5^{-}}(\mathrm{F}+\mathrm{PP})$ & 1.88 & 1.30 & 3.04 & 66.9 & 33.7 & 28.3 & 1.85 \\
\hline $\mathrm{T}_{6^{-}}(\mathrm{F}+\mathrm{W})$ & 1.62 & 1.09 & 2.09 & 57.4 & 34.0 & 19.0 & 1.57 \\
\hline $\mathrm{T}_{7^{-}}(\mathrm{PP}+\mathrm{W})$ & 2.22 & 1.52 & 3.42 & 79.6 & 40.7 & 32.3 & 1.81 \\
\hline $\mathrm{T}_{8}-(\mathrm{F}+\mathrm{PP}+\mathrm{W})$ & 1.32 & 0.92 & 2.05 & 46.9 & 30.8 & 12.6 & 1.42 \\
\hline S.E. \pm & 0.29 & 0.21 & 0.41 & - & - & - & - \\
\hline CD at $5 \%$ & 0.82 & 0.59 & 1.16 & - & - & - & - \\
\hline $\mathrm{CV}(\%)$ & 12.3 & 12.7 & 12.7 & - & - & - & - \\
\hline
\end{tabular}

Produce and input Rates:

\begin{tabular}{|c|c|c|c|c|c|c|c|}
\hline Kharif season & $\begin{array}{c}\text { Groundnut pod } \\
\text { (Rs/kg) }\end{array}$ & $\begin{array}{l}\text { Haulm } \\
\text { (Rs/kg) }\end{array}$ & $\begin{array}{c}\text { Labour } \\
\text { (Rs./day) }\end{array}$ & $\begin{array}{c}\mathbf{N} \\
(\mathrm{Rs} / \mathrm{kg})\end{array}$ & $\begin{array}{c}\mathbf{P}_{2} \mathbf{O}_{5} \\
(\mathrm{Rs} / \mathrm{kg})\end{array}$ & $\begin{array}{c}\text { FYM } \\
\text { (Rs/tonne) }\end{array}$ & $\begin{array}{c}\text { Gr.nut Seed (Pod) } \\
\text { (Rs/kg) }\end{array}$ \\
\hline 2011 & 30.0 & 0.8 & 120.0 & 10.8 & 21.0 & 800.0 & 50.0 \\
\hline 2012 & 30.0 & 1.0 & 120.0 & 10.8 & 21.0 & 1000.0 & 63.0 \\
\hline 2013 & 35.0 & 1.5 & 120.0 & 12.2 & 37.5 & 1000.0 & 63.0 \\
\hline
\end{tabular}


The increase in pod yield with full package of practices over absolute control (full package as per recommendation excluding fertilizer + plant protection + weeding) was 65.51 per cent. Madhu Bala and Kedar Nath, 2015, reported significantly highest pod yield of groundnut by application of full package as per recommendation $(100 \% \mathrm{RDF}+$ weeding + plant protection) over full package as per recommendation excluding fertilizer + weeding + plant protection. These results are in hormone with those reported by Jagtap and Patel, 2015 while working on niger.

Three years pooled data (Table 3) insinuates that, the treatment where application of fertilizers, plant protection and weed control were excluded from full package of practices as per recommendation, gave the lowest pod, kernel and haulm yield (1.32, 0.92 and 2.05 $\mathrm{t} / \mathrm{ha}$, respectively). However, full package of practice as per recommendation was recorded significantly highest pod, kernel and haulm yield (3.82, 2.72 and $4.39 \mathrm{t} / \mathrm{ha}$, respectively) over all other treatments. These results are in line as reported by Patil et al., (2003) while working in safflower.

Groundnut growing with full package of practice as per recommendation excluding fertilizer management $\left(\mathrm{T}_{1}\right.$ - Fertilizer $)$ noticed the lowest pod yield i.e. $2.32 \mathrm{t} /$ ha followed by full package of practice as per recommendation excluding weeding $\left(\mathrm{T}_{1^{-}}\right.$ Weeding) i.e. $2.62 \mathrm{t} / \mathrm{ha}$ and full package of practice as per recommendation excluding plant protection ( $\mathrm{T}_{1}$ - Plant protection) i.e. 3.03 t/ha. Moreover, groundnut exposed to more than one resource constraints, treatment $T_{6}$ $\left(\mathrm{T}_{1}\right.$ - Fertilizer + Weeding) recorded the lowest pod yield of $1.62 \mathrm{t} /$ ha over all other treatments except treatment $\mathrm{T}_{8}\left(\mathrm{~T}_{1^{-}}\right.$Fertilizer +Plant protection + Weeding) which indicates that no use of fertilizer along with non following of the weed management measures proved to be crucial role in reducing the pod yield in groundnut crop.

\section{Economics}

Most of farmers are unable to afford costly agro inputs to grow the groundnut crop. Therefore, present investigation was aimed to minimized the expensive cultivation practices and find out the most appropriate treatment combination. The economic status of each treatment was determined by considering the cost of inputs used and gross returns (Table $3)$. The highest gross monetary return of Rs $1,25,848 /$ ha was observed in full package of practice as per recommendation which includes $100 \% \mathrm{RDF}+$ weeding + plant protection measures, which was followed by the treatment full package of practice as per recommendation excluding the plant protection $\left(\mathrm{T}_{1}-\mathrm{PP}\right)$ i.e. Rs. 1,03,895/ ha which suggest that increase in GMR due to integration of all resources used during cultivation, whereas increase in net monetary returns due to increase in gross monetary returns (Patil et al., 2003; Dwiwedi and Rawat, 2013).

The highest net monetary returns was obtained with full package of practice as per recommendation (Rs.79,107/ ha) over all the treatments. However, the lowest net monetary return was noticed in treatment comprising full package of practice as per recommendation excluding fertilizer +plant protection + weeding $\left(\mathrm{T}_{1^{-}}\right.$Fertilizer + Plant protection + Weeding) i.e. Rs. 12,635/ ha. Such kinds of results are also observed by Jagtap et al., (2014) in niger crop. Benefit cost ratio refers to monetary gain over each rupee of investment under the particular treatment. The treatment full package of practice as per recommendation remained topped in rank with maximum profitability i.e. $\mathrm{B}: \mathrm{C}$ ratio of $1: 2.72$ followed by treatment full package of practice excluding plant protection (1:2.23). These results are in conformity with findings of Madhubala and Kedar Nath (2015), Yadav et al., (2008) and Sharma and Kewat (1994). 
It was concluded from the present investigation, for an optimum productivity and profitability from kharif groundnut under lateritic soils of Konkan, give first preference to fertilizer management followed by weed management and plant protection measures, respectively under the resource constraints.

\section{References}

Anonymous. 2013. Agriculture at a glance. Directorate of Economics and Statistics, Department of Agriculture and Cooperation, Ministry of Agriculture, Government of India, New Delhi.

Dwivedi, B.S. and A.K. Rawat. 2013. Nutrient management technology for niger (Guizotia abyssinica L. F.) crop in tribal areas. Plant Arch., 13(2): 809813.

Jagtap, P.K. and M.C. Patel. 2015. Optimization of Niger (Guizotia abyssinia L. CASS) production under various resource constraints. J. Global Biosci., 4(5): 2315-2318.

Madhubala and Kedar Nath. 2015. Performance of groundnut (Arachis hypogaea L.) as influenced by various resource constraint. Int. J. Dev. Res.,
5(5): 4261-63.

Mukhtar, A.A. 2009. Performance of three groundnut (Arachis hypogaea L.) varieties as affected by basin size and plant population at Kadawa. Ph.D. Dissertation Submitted to Postgraduate School, Ahmadu Bello University, Zaria 173.

Patil, B.B., M.T. Ingavale and K.K. Mangave, 2003. Optimization of safflower production under resource constraints. Madras Agric. J., 90(10-12): 731-733.

Priya, R.S., Chinnusamy, C., Manicaksundaram, P., Babu, C. 2013. A review on weed management in groundnut (Arachis hypogaea L.). Int. J. Agri. Sci. Res., 3: 163-172.

Sharma, R.S. and M.L. Kewat. 1994. Effect of sowing date and fertilizer on yield attributes and seed yield of niger (Guizotia abyssinica) under rainfed condition. Indian J. Agron., 39: 148150.

Yadav, R.A, Mathuria, O.P., Singh, H.P., Yadav, M.P. and Naushad Khan, 2008. Optimization of sesame yield under resource constraints. Plant Arch., 8(2): 999-1001.

\section{How to cite this article:}

Sagvekar, V.V., B.D. Waghmode, A.S. Kamble and Mahadkar, U.V. 2017. Optimization of Groundnut (Arachis hopogaea L.) Production Technologies under Various Resource Constraints in Konkan Region. Int.J.Curr.Microbiol.App.Sci. 6(7): 1498-1503. doi: https://doi.org/10.20546/ijcmas.2017.607.179 